\title{
The Implementation of Quality Management in a Vocational School
}

\author{
Mochammad Churidin Noer \\ Department of Education Management \\ Universitas Negeri Surabaya \\ Surabaya, Indonesia \\ mochammad.18005@mhs.unesa.ac.id
}

\begin{abstract}
The unemployment rate of vocational high school graduates is recorded at the highest of other education levels. The main obstacle is the number of schools with a number of industry is very different. The problem statement in this article is how to implement quality management to a vocational school. Based on the formulation of the problem, the present study aims to find out how the implementation of quality management in the vocational school. Implementation of quality control management in the school from the awareness and commitment of educational units, government and community support, quality of human resources. This research uses descriptive method with a qualitative approach. Data collection techniques carried out by interview, observation and documentation. The subjects in this study were the principal, teachers and employees of the school. The results showed that the vocational high school was guided by the basic principles of integrated quality management. Factors influencing student achievement and improving school performance, first supporting factors: the quality of teacher and principal resources are quite good, adequate infrastructure, high levels of community trust and interest, student guardians and school committees, inhibiting factors: supporting resources are not optimal and the work culture of teachers and employees is not in accordance with integrated quality management.
\end{abstract}

Keywords-implementation; integrated quality management; vocational schools

\section{INTRODUCTION}

To improve the quality of Human Resources (HR), it is necessary to pay attention to education. In other words, a person's education level will significantly influence the quality of HR, of course this is the hope of citizens according to the mandate of the 1945 Constitution and Pancasila as the basis of our country. The concept of quality schools needs to be in the concept of each school principal. Principals need to understand total quality management as a philosophy, method, technique and management strategy for improving school quality, because the performance of school organizations is always valued by the community in increasingly advanced situations like today. The Principal and the teachers need to understand the community's expectations of the school. Integrated quality management is a process of continuous or continuous improvement carried out by schools in order to achieve quality schools. The principal as top management plays an important role in the successful implementation of integrated quality management in schools [1]. Management is a familiar term and is often used in various fields, including in education. Management is an activity to regulate or manage various resources in an effort to achieve a specified result. As stated by Nawawi [2], "management is the ability of leaders (managers) to empower others through the activities of creating and developing cooperation in achieving organizational goals effectively and efficiently".

In the unemployment rate for vocational high school graduates is recorded to be the highest among graduates from other education levels. The main obstacle between the number of school and the number of industries is very different. Abroad, the business world industry is high while Vocational Schools are lacking so that vocational graduates entering the world of industry are very easy, the government has now designed a curriculum that is in accordance with the wishes of the industry, in addition to curriculum there is cooperation that must be interwoven with industries to increase employment opportunities for vocational graduates. This collaboration is the basis of the implementation of integrated quality management in vocational high school in order to produce direct work graduates.

Vocational graduates' competencies can not only be applied in the world of work, but can be demonstrated and tested. Competency testing of vocational students is usually carried out at each level of the learning process takes place, and as a whole is carried out at the end of the school year through activities called expertise competency test, which are under the control of the National Education Standards Agency, both questions, assessment criteria, and testing standards. The expertise competency test assessment does not only involve internal examiners, namely skilled/ productive teachers, but involves external examiners from industry, Professional Certification Institute, or academics who have met the requirements as examiners.

In assignments mandated to a student, research activities for vocational schools conducted by students are activities that encourage students in order to work real to the world of education through various activities that apply appropriate technology, socialization of policies and technical operations of an applied science and can empower quality schools in order to support research activities in this vocational school.

Based on the phenomena that have been described, the author makes an article entitled Integrated Quality 
Management Implementation for Vocational Schools. The problem statement in this article is how to implement quality management in vocational schools. Based on the formulation of the problem above the purpose of this article there is knowing how the implementation of quality management in vocational schools. With the writing of articles for vocational schools, the benefits are as follows.

1. Creating a conducive academic atmosphere for research activities in vocational schools in accordance with the field of science (cluster) in each student and intervocational expertise.

2. Applying appropriate science, innovative and applicable and that can provide real benefits and solve problems for vocational schools and support various school programs.

3. Increasing interaction between students and school members by involving students directly in integrated quality management implementation research programs, so as to improve students' knowledge and ability to interact directly with vocational schools while honing other soft skills.

\section{METHOD}

This research used a qualitative approach with a case study design. Data collected using interview, observation, and documentation techniques. Data were analyzed using data reduction, data presentation, and conclusion drawing. The study was conducted at a Wali Songo vocational high school in Pacet, Mojokerto, East Java. Qualitative research is research that is descriptive and tends to use analysis. The process and meaning (subject perspective) is more highlighted in qualitative research. The theoretical foundation is used as a guide so that the focus of the research is in accordance with the facts in the field. Besides this theoretical foundation is also useful to provide a general description of the background of the research and as a discussion of research results [2].

In this study the authors determined several respondents who were considered relevant and able to provide accurate information. For this purpose the writer met and interviewed the Principal Wali Songo, Deputy Principal, as well as several teachers who were the main subjects. To obtain additional data the author requested the willingness of the Head of Administration of the school.

\section{RESULTS AND DISCUSSION}

\section{A. Integrated Quality Management Concept}

Management is a term that is familiar and often used in various fields, including in the field of education. Management is an activity to organize or manage various resources in an effort to achieve a defined outcome. As stated by Nawawi [3], "management is the ability of leaders (managers) in utilizing others through activities to create and develop cooperation in achieving organizational goals effectively and efficiently".

Integrated quality management is a comprehensive philosophy of life and life and organizational activities that emphasize continuous improvement as a fundamental goal to improve quality, productivity, and reduce financing [4]. The term that concludes with TQM is continuous quality improvement (CQI) or continuous quality improvement. But TQM focuses on the process or system for achieving organizational goals.

In Murniati, TQM is defined as "Management approach of an organization, centered on quality, based on the participation of all members and customer satisfaction, and benefits to all members of the organization and to society [3]. Thus, TQM as a management approach in an organization directed at quality and based on a set of basic principles that aim to increase the long-term success of the organization through customer satisfaction and the benefits of all members of the organization.

Basically TQM in the world of education, according to Sallis [2], is a process that involves focusing on meeting and exceeding consumer expectations, continuous improvement, sharing responsibilities with employees, and reeducating staffs and rework. This means that integrated quality of education is understood as a process that involves concentrating on achieving satisfaction with customer education expectations, continuous improvement, sharing responsibility, with employees, and reducing the remaining work and workmanship.

Basically "Total Quality High Schools" have five characteristics identified from the quality pillars, namely:

\section{Focus on customers}

In the context of education, schools are an educational service and not a form of production. Product quality is an intermediate target because the most important goal in implementing TQM is higher customer satisfaction. The customer is someone who uses educational services. Thus anyone who provides information, and or services to someone in a school organization, then that person is the customer [5]. Whereas according to customers are all people who demand an organization to meet certain quality standards and therefore will have an influence on the organization's performance [5]. Therefore, everyone who is in the school system, whose services contribute to the school process, namely: students, teacher staff, principals, employees are customers.

\section{Total involvement}

School quality is not only the responsibility of school leaders or school committees or teachers or supervisors. But the quality of the school is the responsibility of all parties. Therefore, contributions from each school member are needed to improve the quality of education in school. Involvement of all school people in one

School organizations have three elements, namely: (1) the existence of an educational process to support the message of total quality management, (2) the existence of participation in the form of work teams to provide an institutional problem solving action in schools, (3) changes in work arrangements in school.

\section{Measurement}

In the process of improving quality in schools a measurement is needed in order to meet the quality standards 
that have been set. With this measurement, data can be collected, then the data analysis results obtained information that can be used as a basis for decision making.

\section{Commitment}

All school residents must be committed to improving the quality of the school. This commitment is the first step in the quality transformation process. Everyone needs to support school quality efforts.

\section{Continuous improvement}

Continuous improvement means that the management of a school organization must aim at improving a steady increase in the overall performance of the organization of the school. Continuous improvement allows school organizations to monitor work processes that have been carried out so they can identify opportunities for improvement. With this continuous improvement, continuous evaluation and improvement can be made of the work processes that have been carried out in the school, so that the performance of the school organization increases.

\section{B. Application of Integrated Quality Management}

In the context of education, TQM is still relatively new. The first initiatives to implement this method were seriously carried out in American and British schools in the early 1990s. Sallis defines the TQM concept in education as follows: "TQM is a philosophy of continuous improvement, which can provide any educational institutions with a set of practical tools for meetings and exceeding present and future customer needs, wants and expectations.". This definition provides an understanding that TQM is a philosophy of continuous improvement that can provide a set of practical tools for each educational institution in meeting the needs, desires, and expectations of its customers, now and in the future (Bestefe, 1999). Thus, the application of TQM is very helpful for educational institutions in managing change and arranging an education program agenda to meet the expectations of its customers. As stated by Sallis that: "Total Quality Management is a philosophy and methodology which helps institutions to manage change and set their own agendas for dealing with the plethora of new external pressures" [6]

Thus, the application of TQM in school organizations is carried out as an effort to improve the quality of education in schools, so that schools are able to create competitive advantages for graduates with high quality education. TQM is a very necessary thing because there are currently no educational institutions that are not oriented towards improving the quality of their education. Regarding the application of TQM, Fields stated that the application of TQM in the field of education was carried out in the form of principles [4]. Even the application of TQM principles will show positive results, so schools adopt TQM as a process of improving and rebuilding education in their schools.

The principles in TQM are like a pillar that gives strength in moving school organizations. With this pillar, it is expected to be able to help school organizations in improving their educational processes. Mentions several functions of applying the principles in TQM, namely: (1) providing a map of the direction of a school change, (2) helping collaboration as a school work team, (3) making a school program holistic , (4) increasing the participation of all people to be involved in school management, (5) developing cooperation with parents and students in setting quality standards for school education, and (6) making all school citizens to act proactively [6]. Thus, the principles of TQM are very important for school organizations because they are the basis for implementing TQM in the school.

Quality management that is adapted to the basic characteristics of education. The customer side, namely students, parents and society is the main focus. By combining quality principles by experts with practical experience the development of a simple but very effective model for implementing integrated quality management in schools has been achieved. Teachers are the main element in the whole process of education, especially at the institutional level. Without the teacher, education is only a grandiose slogan because all forms of policies and programs will ultimately be determined by the performance of those at the forefront, namely the teacher.

Therefore, the effort to realize a total quality school is required to focus on its customers, the total involvement of all school members, the existence of a measure of educational quality standards, view education as a system and make continuous improvement in the quality of education. Thus, the application of the TQM principles in school education has been inevitable and bargained again by school managers. Because the implementation of quality education in schools has become an absolute demand from all levels of society, both students, parents, society, further education, government and the business world. The process of going to school is of total quality, the principal, school committee, teachers, staff, students and all school members must have a commitment to quality, namely quality education. Having a vision and mission of quality that is focused on meeting the needs and expectations of its customers, both internal customers, such as teachers and staff, as well as external customers such as students, parents of students, society, government, further education and the business world. Thus, the implementation of integrated quality management in Vocational Schools will produce quality vocational graduates, namely graduates with high competency and obtaining certification in the industry, so that they can obtain the recognition of qualifications equivalent to Diploma-2 level. This can be done based on quality-oriented school programs that form the basis of school development. Schools are based on the vision and mission of schools that are oriented towards the quality of education. Schools have the quality beliefs and values that the school holds.

There is one main point that needs to be used as a benchmark for improving quality in vocational schools, namely the Expertise Competency Test. expertise competency test is part of the Government program in ensuring the quality of education in the Vocational High School education unit. The implementation of the expertise competency test aims to measure the achievement of students' competencies at a certain level according to the Expertise Competencies taken during the learning period at Vocational Schools. Expertise competency test is carried out by educational units in the form of practical 
examinations that test aspects of knowledge, skills and attitudes at one event.

Expertise competency test can be implemented using industry-set standards, Professional Certification Institutions, and or test equipment issued by the Ministry of Education and Culture in the place of competency testing. The education unit that organizes expertise competency test must be declared eligible as a place of competency testing by the Provincial Level National Examination coordinator or Professional Certification Agency. As in the previous year, the value of expertise competency test will be calculated as the School Examination Value for vocational competency subjects.

The expertise competency test tool issued by the Ministry of Education and Culture is open and test participants can practice using the test kit before conducting the exam. In general, the Expertise Competency Test device consists of:

1. Vocational Practice Problems are in the form of assignments for test participants to make or process and work on a product or service.

2. Guidelines for Practice Question Assessment are instruments used to score each component of the assessment. The assessment sheet contains assessment components, assessment sub-components, competency achievement, and assessment criteria/ rubrics

3. The Verification Instrument Provider of the Vocational Practice Examination is an instrument used to assess the feasibility of an educational unit or other institution as a place for conducting Vocational Practice examinations. The verification instrument contains the standards for the main equipment requirements, the standard requirements for supporting equipment, the standard place/ space requirements and contains the testing requirements consisting of internal and external testers

Assessment of expertise competency test in vocational high school is ideally carried out in industry or by assessors from industries or the business world. Assessments relating to competency certification are carried out by independent certification bodies in accordance with their expertise. If this institution is not yet available, the school can work with the business/ related industries that have the credibility to act as a substitute for the certification body. However, considering that the budget is not yet possible, it cannot yet be implemented because to test competency in Professional Certification Institutions or industry, it requires not a small amount of money. Alternative to conducting vocational competency tests, namely through the Regional Certification Coordination Agency. It's just that the costs needed are no less expensive. It will burden the students more, moreover it is difficult to find assessors from the industrial world because of the limited number.

In fact, in the implementation of the expertise competency test in several Vocational High Schools that the author has participated in, not all of the examiner's requirements can be fulfilled. Internal examiners who come from productive field teachers have not all had certificates and bachelor education background, so in this case the consideration of equal opportunity becomes a test for teachers productive who have a minimum of 3 years working period applied by the Vocational School. External examiners on the implementation of expertise competency test in school prioritize more on examiners from the business/ industry who have collaborated (as partners) with schools, especially industries where students carry out internship, regardless of educational background or certificate as examiners who it has. Schools prefer to choose testers from industry elements rather than testers from non-formal training/ education institutions who have certified examiners.

Expertise competency test is implemented by using established standards. The education unit that organizes expertise competency test must be declared eligible as a place of competency testing by the Provincial Level National Examination coordinator or Professional Certification Agency. The practical examination instruments issued by the Ministry of Education and Culture are open so that examinees can practice using the test instruments before conducting the exam. The results of the Expertise Competency exam from students will be an indicator of achievement of graduate competency standards, while for stakeholders will be used as information on competencies possessed by students, for which tools and mechanisms are needed to strengthen stakeholder recognition. The mechanism and learning process at the Vocational High School is organized with a competency-based approach and is designed to be relevant to the competency requirements required by the world of work.

In its implementation students gain learning experience to be able to develop their respective potentials and master thoroughly (material) step by step the competencies that are being studied. One of the learning strategies in Vocational Schools is learning that is designed to be implemented in the form of working directly in the production process as a vehicle for learning (production-based training) so that students get work experience while honing their competencies.

Skills competency exams for vocational students include varied Expertise Competence subjects, until now it has a spectrum of expertise of 121 expertise competencies. For this reason, it is necessary to formulate a pattern of education that can serve the needs of the current diversity of vocational schools. Skills competency test subjects are designed to be able to measure the level of knowledge, skills, and behavior of students towards competencies according to the characteristics of competency skills. For this reason, expertise competency exam questions are developed in the form of Vocational Theory and Vocational Practice tests which are carried out individually.

Based on the data obtained it was found that vocational practice exams were carried out using standards set by the industry, Professional Certification Institutions and test kits issued by the Ministry of Education and Culture in competency test sites. Educational units that conduct vocational practice tests must be declared as suitable places for competency tests by the Provincial Level National Examination coordinator or Professional Certification Agency. The set of practical tests issued by the Ministry of Education and Culture are open and test participants can practice using the test set before the test. Expertise competency test results from students will be indicators of achievement of graduate competency standards, 
while for stakeholders will be used as information on the competencies possessed by prospective workers, for this we need tools and mechanisms to strengthen stakeholder recognition.

The results showed that the implementation of the vocational competency test was carried out in accordance with the Guidelines issued by the Directorate of Vocational High School Development. This proves that the implementation of the competency test runs well in order to improve school quality and apply integrated quality management. The implementation of the vocational competency test has the recognition of its cooperation with industry and several related agencies is a good partner. The results of this vocational competency test can also be an illustration that the results of vocational high school graduates are indeed quite good for industries and agencies that need workers who have competence in their fields.

\section{CONCLUSION}

Integrated quality management currently carried out by the school under study, in principle has been carried out in accordance with applicable rules and guidelines in improving the quality of education. However, there are still obstacles in terms of adjusting the results of graduates with related parties such as the business world and industry, where graduates after graduation still need certain skills to suit the needs of the business and industry.

At the time of the competency test of expertise, many students feel less material in dealing with. This happened because at the time of the expertise competency test, there were several students who were not in accordance with the fields that should have been the focus of skills development in accordance with the direction he had chosen. In addition, the quality policy and implementation strategy in implementing new quality assurance is seen as a slogan or only to meet the needs of accreditation, not all the schools concerned refer to the quality policies that have been set in carrying out educational operations that can improve the quality of education.

Quality Management Education in vocational high schools is one of the ways of working in management that has 4 principles, namely: customer satisfaction, leadership, continuous improvement and human resource management. Education Quality Management makes vocational high schools able to provide services that meet the needs and desires of consumers, which refer to quality education.

The implementation of quality control management in vocational schools is born from the awareness and commitment of educational units, full support from the government and society, improving the quality of human resources, available budgets, authority and autonomy of education units, application of information technology, networks and partnerships with good stakeholders and strong leadership. Then, in terms of administration, it is needed educational quality documents and student coaching, standard operating procedures, quality control management, and quality management evaluation instruments.

\section{REFERENCES}

[1] Bestefe. 1999. Total Quality Management in Education 3rd Edition. London: Kogan Page Ltd.

[2] J Edward Sallis. 2002. Total Quality Management in Education Third Edition. London: Kogan Page Ltd.

[3] Franklin P. Schargel. 1994. Transforming Education Through Total Quality Management: Practitioner's Guide. New York: Eye on Education.

[4] Sherr, Lawrence \& Lozier, Gregory. 2004. Total Quality Management in Higher Education. pp. 68-72.

[5] M. AR and N. Usman, Implementasi Manajemen Stratejik Dalam Pemberdayaan Sekolah Menengah Kejuruan, Bandung: Cita Pusaka Media., 2009 .

[6] J. E. Sallis, Total Quality Management in Education, London: Kogan Page Ltd, 2002.

[7] B. E. Denham, Categorical Statistics for Communication Research, Malden: John Wiley \& Sons, Inc., 2017. 